\title{
Multi-Locational Evaluation of Medium-Staple Cotton Genotypes for Seed-Cotton Yield under the Middleveld Agro-Ecological Zones of Zimbabwe
}

Marco Mare ( $\square$ marcomare82@yahoo.com )

Cotton Research Institute

Blessing Chapepa

Cotton Research Institute

Washington Mubvekeri

Cotton Research Institute

\section{Research}

Keywords: Cotton, Gossypium Hirsutum, GGE, Genotype, Environment, Stability, Yield, Adaptability

Posted Date: August 27th, 2020

DOI: https://doi.org/10.21203/rs.3.rs-43613/v2

License: (c) (i) This work is licensed under a Creative Commons Attribution 4.0 International License.

Read Full License 


\section{Abstract}

\section{Background}

The Zimbabwean national cotton breeding programme has the mandate to develop superior cotton (Gossypium Hirsutum) varieties with good field performance and high fibre properties. Cotton productivity in Zimbabwe has remained very low, with national average seed cotton yield record of $650 \mathrm{~kg} \mathrm{ha}^{-1}$ (AMA Report, 2019) compared to the potential $2000 \mathrm{~kg} \mathrm{ha}^{-1}$. Since this is a result of many biotic and abiotic factors, field experiments laid in a Randomized Complete Block Design were conducted on ten genotypes (seven test genotypes and three check varieties) from 2012 to 2019 across 13 diverse locations in Zimbabwe to evaluate cotton yield performance, stability and adaptability by Analysis of Variance (ANOVA) and Genotype and Genotype by Environment Interaction (GGE) Biplot methods.

\section{Results}

The Analysis of Variance indicated significant $(P<0.001)$ effects of Genotype $(G)$, Environment $(E)$ and their Interaction (GE). The highest percentage of variation was explained by E/G/GE (60.34\%) while $\mathrm{G} / \mathrm{E}+\mathrm{GE}$ together explained the rest of the variation ( $<40 \%)$. Joint effects of $\mathrm{G}$ and $\mathrm{GE}$ were partitioned using the GGE biplot analysis explaining total of $59.08 \%$ (PC1 $=36.96 \%$ and PC2 $=22.12 \%$ ) of the GGE sum of squares. The biplot analysis revealed that candidates 917-05-7, TN96-05-9, 912-05-1 and GN 96 (b)-05-8 were the ideal and stable genotypes. The candidate variety 917-05-7 significantly $(P<0.001)$ showed superior yield performance over checks CRI-MS1 and CRI-MS2 recording 5\% and 5.5\% yield increase respectively. Candidate $917-05-7$ recorded a higher earliness index $(78.11 \%)$ over checks CRIMS1 and CRI-MS2 (77 and 76\% respectively) thus indicating potential attributes for good cotton production with more pick-able bolls earlier than the current commercial varieties.

\section{Conclusion}

Candidate 917-05-7 has been identified as the ideal genotype in terms of high yielding potential, and stability hence recommended for commercial release and use as breeding parent for future breeding programs.

\section{Background}

Cotton (Gosspyium Hirsutum) is predominantly a smallholder crop and represents a crucial source of income for millions of farmers and their families in more than 20 countries across all regions of SubSaharan Africa (Travella 2017). Despite its economic potential, cotton variety development in Zimbabwe has been very low leaving farmers to continuously cultivate obsolete varieties. Currently cotton production in Zimbabwe is very low, with national average seed cotton yield of $650 \mathrm{~kg} \mathrm{ha}^{-1}$ (Fig. 1)

The cotton genotype selection and recommendations by breeders has been slowed down due to the effects of genotype by environment interaction (GEI). This complicates the identification of superior 
cotton genotypes, thus making selection and recommendation of new genotypes for different environments difficult and expensive (Mare et al. 2017; Mukoyi et al. 2018). Some multi-locational field experiments from 2012 to 2019 growing season were conducted aiming to evaluate relative response of cotton genotypes across different environments and identify varieties with good adaptation and stability (Baafi and Safo-Kantanka 2008) through use of GGE biplot analysis. Multilocational Yield Trials (MYT) are important to evaluate the relationship between genotypes and environments for selected traits by use of a genotype by genotype by environment (GGE) biplot that allows visual assessment of genotype by environment interaction (GEI) pattern (Yan et al. 2000; Yan and Hunt 2001). GGE is the most recent approach proposed by Yan et al. 2000, and has shown extensive usefulness and a more comprehensive tool in quantitative genetics and plant breeding (Yan et al. 2001; Yan and Rajcan 2002). This tool for analysis of GEl is increasingly being used in GEl studies in plant breeding research (Butran et al. 2004). The objectives of this study were (i) to identify the genotype and environmental components that are associated with the GXE interaction across the diverse environments, looking at percentage source of variation and joint effects of $G$ and $G E$ as partitioned by Principal Components (PC) in the total sum of squares, (ii) to identify the ideal genotype(s) based on high yielding potential and stability across test-locations, (iii) to identify mega, representative and ideal environment for testing genotypes and (iv) to identify which variety won where of the given test-locations.

\section{Materials And Methods}

\section{Study Sites}

The multi-locational experiments were conducted for six seasons (2011/2012, 2013/2014, 2015/2016, 2016/2017, 2017/2018 and 2018/2019 growing seasons) at four On-station sites (Cotton Research Institute, Panmure Experiment Station, Chisumbanje Experiment Station, and Save Valley Experiment Station) and eight Off-station sites (Matikwa, Shamva, Kuwirirana, Muzarabani, Wozhele, CC Mollen, Umguza and Chitekete). The sites represent the high cotton production zones, thus the Middleveld, and Lowveld. The sites are generally characterized with low average annual rainfall $(<800 \mathrm{~mm})$ and high temperatures $\left(>36^{\circ} \mathrm{C}\right)$. General description of the sites encompassing longitude, altitude acetra, is given in Table 3.

Table 3: Description of sites used in the multi-locational trials 


\begin{tabular}{|c|c|c|c|c|c|c|}
\hline ocation & Code & Latitude & Longitude & Altitude & Av. Annual Rainfall & Max Temp ${ }^{0} \mathrm{C}$ \\
\hline hitekete & E1 & $17^{\circ} 25^{\prime}$ South & $28^{\circ} 56^{\prime}$ East & 914 & $450-500$ & 45 \\
\hline adoma & $\mathrm{E} 2$ & $18^{\circ} 19^{\prime}$ South & $29^{\circ} 53^{\prime}$ East & 1156 & $750-1000$ & 38 \\
\hline Tozhele & E3 & 19³1' South & $30^{\circ} 14^{\prime}$ East & 1345 & $650-790$ & 37 \\
\hline uwirirana & E 4 & $21^{\circ} 15^{\prime}$ South & $30^{\circ} 48^{\prime}$ East & 1483 & $500-600$ & 38 \\
\hline [atikwa & E5 & $20^{\circ} 48^{\prime}$ South & $32^{\circ} 14^{\prime}$ East & 300 & $450-500$ & 40 \\
\hline hamva & E6 & $17^{\circ} 32^{\prime}$ South & $31^{\circ} 71^{\prime}$ East & 1149 & $675-700$ & 38 \\
\hline [uzarabani & E7 & $16^{0} 23^{\prime}$ South & $31^{\circ} 00^{\prime}$ East & 432 & $600-800$ & 42 \\
\hline anmure & E8 & $17^{\circ} 16^{\prime}$ South & $31^{\circ} 47^{\prime}$ East & 881 & $700-800$ & 35 \\
\hline C Mollen & E9 & $18^{\circ} 30^{\prime}$ South & $29^{\circ} 13^{\prime}$ East & 1120 & $700-850$ & 38 \\
\hline ave Valley & E10 & $21^{\circ} 29^{\prime}$ South & $32^{\circ} 51^{\prime}$ East & 466 & $450-500$ & 41 \\
\hline hisumbanje & E11 & $20^{\circ} 47^{\prime}$ South & $32^{\circ} 13^{\prime}$ East & 448 & $450-500$ & 40 \\
\hline mguza & E12 & $20^{\circ} 03^{\prime}$ South & $28^{\circ} 34^{\prime}$ East & 1374 & $450-500$ & 34 \\
\hline
\end{tabular}

Source: Agritex planning branch, (2019): Zimbabwe natural regions and farming areas boundaries

\section{Experimental Description and Design}

The experiment included ten genotypes thus seven test genotypes (TN 96-05-9, 912-05-1, S099-9, GN 96 (b)-05-8, 917-05-7, 932-05-3 and 938-05-3) and three check varieties (SZ9314, CRI-MS1 and CRI-MS2 (Table 4). All the test-genotypes were developed by Cotton Research Institute using the Pedigree Breeding Method. The experiments were laid in a Randomized Complete Block Design replicated three times and each treatment was represented by plots measuring $32.4 \mathrm{~m}^{2}$.

Table 4: Description of Cotton genotypes used in the multi-locational trials 


\begin{tabular}{lcll}
\hline Genotype Name & Code & Type \& breeding status & Origin \\
\hline TN 96-05-9 & G1 & Experimental Line & Cotton Research Institute \\
912-05-1 & G2 & Experimental Line & Cotton Research Institute \\
\hline S0-99-9 & G3 & Experimental Line & Cotton Research Institute \\
\hline GN 96 (b)-05-8 & G4 & Experimental Line & Cotton Research Institute \\
\hline 917-05-7 & G5 & Experimental Line & Cotton Research Institute \\
\hline 932-05-3 & G6 & Experimental Line & Cotton Research Institute \\
\hline 938-05-3 & G7 & Experimental Line & Cotton Research Institute \\
\hline SZ9314 & G8 & Commercial Check Variety & Cotton Research Institute \\
\hline CRI-MS1 & G9 & Commercial Check Variety & Cotton Research Institute \\
\hline CRI-MS2 & G10 & Commercial Check Variety & Cotton Research Institute \\
\hline
\end{tabular}

\section{Trial/ Crop Management}

Uniform crop management was done at all the sites and across all the various projects in the programs. Compound L (N: P: K: S = 5:18:10:8: $\{0.25 \mathrm{~B}\})$ was banded at a rate of 250 $\mathrm{kg} \mathrm{ha}^{-1}$ to the planting furrows manually. Ammonium nitrate $(34.5 \% \mathrm{~N})$ was applied at a rate of $150 \mathrm{~kg} \mathrm{ha}^{-1}$ to the crop at the ninth week after crop emergence. The crop was thinned to one plant per station at $1 \mathrm{~m}$ inter-row by $0.3 \mathrm{~m}$ within row to achieve a desired plant population of about 33333 plants ha ${ }^{-1}$. Weeding using herbicides and hand hoeing was done to remove any weeds from the trials when necessary. Weeding at all sites was averagely done three times for the whole season. The following cotton pests were controlled using the general recommended cotton pest scouting and control protocol developed at Cotton Research Institute in 1993 by the Cotton Research Institute entomology section (Annual Report, 1993). The pests controlled were: aphids (Aphis gosypii), red boll worms (Diaparposis castanea) and Heliothis bollworm (Helicorvepa amirgera). Pests were kept at below the economic thresholds levels following weekly scouting.

\section{Field Data Collection and Analysis}

Crop performance data from emergence to post-harvest (seed cotton yield, lint yield, seed weights, boll weights, seed weights, lint ratios, earliness index) was collected from all experiments. The genotype and genotype by environment (GGE) model was used to understand and structure interactions between genotypes and the environment. The model was used to identify mega, representative and ideal environment for testing genotypes. The 
Principal Component Analysis (PCA) was used to explain patterns in the Genotype $\mathrm{x}$ Environment interaction. It was also used to identify superior genotypes and estimate adaptability and stability of the genotypes across the sites in different years. GenStat $14^{\text {th }}$ edition for windows was the statistical software for the partitioning of the variance components (general combined analysis of variance (ANOVA). Where significance difference was noted, treatments means were separated using the Fischer's (1930) Least Significant Difference at $P \leq 0.05$ (Williams and Abdi 2010).

\section{Results}

An across seasons and environments, general combined analysis of variance (ANOVA) was conducted and the results indicated that variance on the measured yield and yield-related traits was due to the presence of genotype by environment interaction (GEI) $(P<0.001)$ except for boll weights. The highest percentage of variation was explained by $E / G / G E$ (60.34\%) while G/E+GE together explained the rest of the variation (<40\%) (Table 1). Joint effects of $\mathrm{G}$ and GE were partitioned using the GGE biplot analysis explaining total of $59.08 \%$ (PC1 $=36.96 \%$ and PC2 $=22.12 \%$ ) of the GGE sum of squares (Table 1 ). The effect of GxE interaction on the parameters invited the need for further analysis using the GGE biplot analysis to be able to identify genotypes which are stable and adaptable. Overall seed cotton yield mean for the candidates was $1663 \mathrm{~kg} \mathrm{ha}^{-1}$, whilst candidate recorded $1755 \mathrm{~kg}$ ha $^{-1}$ (Table 2) which was $5 \%$ and $5.5 \%$ yield gain over checks CRI-MS1 and CRI-MS2 respectively (Fig. 2).

Table 1: Summary of the general analysis of variance for grain yield $\left(\mathrm{kg} \mathrm{ha}^{-1}\right)$ showing the level of significance for the genotype, environment and GEI of advanced cotton genotypes

\begin{tabular}{lllllll}
\hline Source of variation & d.f. & s.s. & m.s. & v.r. & Fpr. & Exp\% ss \\
\hline Genotype (G) & 9 & 5618628 & 624292 & 4.93 & $<.0 .001$ & 14.06 \\
Environment (E) & 11 & 227076442 & 20643313 & 163.18 & $<.0 .001$ & 25.6 \\
\hline Genotype x Environment (GEI) & 99 & 15502745 & 156593 & 1.24 & 0.005 & 60.34 \\
Residual & 234 & 29433635 & 42169 & & & \\
\hline Total & 353 & 277631450 & 786491 & & & \\
\hline
\end{tabular}

\footnotetext{
** $\mathrm{DF}=$ Degrees of freedom; $\mathrm{SS}=$ sums of square; $\mathrm{MS}=$ means square.
} 
Table 2: Overall Field performance of the genotype 917-05-7 against three commercial check cultivars during the 7 seasons (2012-2019)

\begin{tabular}{|c|c|c|c|c|c|c|}
\hline Genotype name & $\begin{array}{l}\text { Seed cotton yield } \\
\left(\mathrm{kg} \mathrm{ha}^{-1}\right)\end{array}$ & $\begin{array}{l}\text { Boll weight } \\
\text { (g) }\end{array}$ & $\begin{array}{l}\text { Earliness } \\
\text { Index } \\
(\%)\end{array}$ & $\begin{array}{l}\text { Gin out } \\
\text { Turn } \\
(\%)\end{array}$ & $\begin{array}{l}\text { Lint } \\
\text { Yield } \\
\left(\mathrm{kg} \mathrm{ha}^{-1}\right)\end{array}$ & $\begin{array}{l}100 \text { seed weight } \\
\text { (g) }\end{array}$ \\
\hline $917-05-7$ & $1755^{\mathrm{d}}$ & 6.4 & 78.11 & 41.83 & 743.9 & 10.88 \\
\hline CRI-MS-1 & $1677^{\mathrm{bcd}}$ & 6.3 & 77.04 & 42.12 & 717.9 & 11.40 \\
\hline CRI-MS-2 & $1659^{\mathrm{bcd}}$ & 6.3 & 76.13 & 41.54 & 709.1 & 10.96 \\
\hline SZ9314 & $1737^{\mathrm{cd}}$ & 6.3 & 78.58 & 41.92 & 744.7 & 11.06 \\
\hline Grand Mean & 1663 & 6.4 & 77.4 & 41.8 & 709.8 & 11.12 \\
\hline F-Pro (G) & $* * *$ & $* * *$ & $* *$ & ns & Ns & $* * *$ \\
\hline F-pr (G x E) & $* *$ & ns & $* * *$ & $* * *$ & $* * *$ & $* * *$ \\
\hline Av. SED & 60.34 & 0.1163 & 1.278 & 1.249 & 27.6 & 0.081 \\
\hline $\mathrm{CV} \%$ & 21.2 & 10.91 & 9.98 & 17.78 & 21.26 & 4.31 \\
\hline
\end{tabular}

-Sig - Significance level, LSD Least Significant Differences, CV\% Coefficient of Variation, SE Standard Error of Differences, *** significantly different at $<0.001, * *$ - significantly different at $<0.01$, * significantly different at $<0.05$, NS - Not significantly different.

NB: The Grand mean, F-pr, LSD and CV\% values displayed above are for the whole trial (all the genotypes).

Genotype Stability Analysis (GEI) for total seed cotton yield for cotton genotypes across seasons and environments

\section{Which-won-where and mega-environments (ME)}

The GGE scatter plot (Fig. 3) showed dissected pentagon into sectors with winning genotypes located at the vertex of the polygon. The biplot revealed that candidate 917-05-7 (G5) and TN96-05-9 were the winning genotypes in six environments (Chisumbanje Exp, Umguza, Muzarabani, Matikwa, Panmure and Save Valley) which fell under that sector/ mega-environment 1. The biplot revealed the existence of three Mega-environments (ME), with ME1 comprised of Chisumbanje Experiment Station, Umguza, Muzarabani, Matikwa, Panmure Experiment Station and Save Valley Experiment Station, ME2 comprised of Chitekete, CC Mollen and Cotton Research Institute where CRI-MS1 was the winner whilst ME3 consisted of Wozhele, Kuwirirana and Shamva where SZ9314 was the winner.

\section{Genotype Ranking based on mean performance and stability}

Genotype by genotype-by-environment (GGE) interactions biplot analysis revealed that candidate 917-05-7 was high yielding and stable thus located on the far right and a short 
projected perpendicular line to the environmental axis whilst candidate TN96-05-9 was more stable and above average in terms of yield performance (Fig. 4). Candidate 912-05-1 was moderately yielding thus above average and very stable. So candidates 917-05-7, TN96-05-9 and 912-05-1 are selected as good varieties which are high yielding and stable compared to the check varieties CRI-MS1 and SZ9314 which were around average yield performance and highly unstable.

\section{Ideal Genotype and environment}

The GGE analysis positioned the candidate genotype 917-05-7 in first concentric ring (Fig. 5), identifying it as the ideal genotype. This also reveals that the genotype is high yielding and moderately stable compared to check varieties which positioned in the $11^{\text {th }}$ concentric ring thus low yielding and unstable. Some good varieties closer to the ideal genotypes were shown, and these included TN96-05-9, 912-05-1 and GN 96 (b)-05-8. The biplot displayed Umguza as the most ideal environment (Fig. 5) identified by its location in the second concentric circle. However, Umguza showed poor discriminating ability as compared to Save Valley Experiment Station which had the best discriminating ability thus gave more information about the performance of tested genotypes. This indicates that the GEI greatly influenced the effect of Umguza site to the performance of the test-genotypes. Good environments such as Matikwa, Save Valley Experiment Station and Chisumbanje Experiment were displayed.

\section{Discussion And Conclusions}

The general analysis of variance recorded candidate genotype 917-05-7 as the highest yielding (1755kg

${ }^{1}$ ) over the check varieties $\left(<1680 \mathrm{~kg}^{-1}\right)$ across seasons and environments by recording $>5 \%$ yield advantage more than the commercial check varieties. The GGE biplot analysis was successful in giving more information about the test genotypes and test environments which could not be synthesized by analysis of variance (ANOVA) only. Biplot analysis revealed good varieties based not only on high yielding but stability, which is very important when yield experiments are done in many different environments. Candidate variety 917-05-7 was the ideal variety based on high mean yield performance and stability, and candidate variety TN96-05-9 was a good variety which was moderately yielding and very stable (Nzuve et al. 2013; Mudada et al. 2017). Other candidate genotypes such as 912-05-1 and GN 96 (b)-05-8 were presented as good varieties with high and moderate stability respectively. The biplot analysis gave more information about the relationship between environments and genotypes (Zeng et al. 
2014), whereby high mean performing environments with high discriminating ability were revealed, the identified sites were Umguza and Save Valley Experiment Station respectively. Umguza recorded high mean yield but was not well discriminating whilst Save Valley was moderately high yielding and high discriminating compared to the other environments. Good environments such as Matikwa, Save Valley Experiment Station and Chisumbanje Experiment Station were displayed in the biplot graphs. Three mega environments (ME) were shown through the GGE biplot analysis, and candidate varieties 917-05-7 and TN96-05-9 were the winning genotypes for ME1 which consisted of six environments out of twelve. The information revealed on mega-environments was relevant to the general information about the experimental sites where all the Lowveld institutes fell (Save Valley Experiment Station and Chisumbanje Experiment Station) in one Mega Environment (Mare et al. 2017; Simasuku et al. 2020). This means no much differences were realized in terms of their effect on the variety performances and the sites are similar. This study was relevant in context of making good progress in selecting the best ideal and stable varieties under multi-locational variety trials. The study with reference to Zimbabwe's national cotton variety development programme enabled the breeder to efficiently select and recommend superior genotypes for further evaluations and subsequent release (Yan et al. 2001; Yan and Rajcan 2002). The use of GGE biplot analysis in the study showed extensive expediency in quantitative genetics and plant breeding hence the researcher implies this as a more comprehensive and relevant tool in multilocational research trials. Henceforth, the study results have identified genotypes 917-05-7, TN96-05-9, 912-05-1 and GN 96 (b)-05-8 as the superior candidates for commercial use as varieties and as parents for future hybridization programmes.

\section{Abbreviations}

CRI

AMA

GGE

PCA

ME

ANOVA

GEI

RCBD

E

G

DF
Cotton Research Institute

Agricultural Marketing Authority of Zimbabwe

Genotype and Genotype by Environment

Principal Component Analysis

Mega Environment

Analysis of Variance

Genetic by environmental interaction

Randomized complete block design

Environment

Genotype

Degrees of Freedom 


\section{Declarations}

Ethics approval and consent to participate

Not Applicable

\section{Consent for publication}

Not Applicable

\section{Availability of data and materials}

The data (Analyzed) was generated through some institutional programmes and it is contained in this paper and access to the raw data is not publicly available

\section{Competing interests}

The authors declare that they do not have competing interests

\section{Funding}

All the funding of the research work was supported by the Cotton Research Institute through the Department of Research and Specialist Services

\section{Authors' contridutions}

Mare $\mathrm{M}$ collected, analyzed and interpreted the data, as well as writing the research paper

Chapepa B assisted in the collection of data and analysis

Mubvekeri W assisted in editing of the research paper, and guided in data analysis 


\section{Acknowledgements}

The Researcher would like to thank Cotton Research Institute (CRI) team and the Government of Zimbabwe for the unwavering technical and financial support through Department of Research and Specialist Services in the Ministry of Lands, Agriculture, Water, Climate and Rural Resettlement. The success of the cotton evaluation trials was due to good relationship and collaboration between researcher, the Cotton Research Institute and all other stakeholders both in the public and private sectors of Zimbabwe. Further appreciation goes to the Agricultural Marketing Authority (AMA) for providing financial support to the Cotton Variety Development programme at CRI and that enabled the establishment and management of multi-environment trials from which data was generated. Special thanks also go to farmers in Gokwe, Sanyati, Dande, Muzarabani, Shamva and the South East Lowveld for their participation in the off-station trial implementation, management the Cotton Breeding Team who assisted in data entry. The Researcher would further like to thank the co-authors, Chapepa B and Mubvekeri $\mathrm{W}$ for their support in making the study sail through successfully.

\section{Authors' Information}

MARE Marco the corresponding author is a Cotton plant breeder with Cotton Research Institute and holds MSc degree in plant breeding and genetics. He has 16 years' experience working as plant breeder on various crops such as sorghum, pearl millet, finger millet, cowpeas and cotton and in different institutions such as ICRISAT and Crop Breeding Institute in Zimbabwe.

\section{References}

1. Agricultural Marketing Authority. Cotton production trend 2019 (average yield, production and area under production) for the period 2008 -2018

2. Agritex planning branch. Zimbabwe natural regions and farming areas boundaries, 1983. The department of conservation and extension; Agritex

3. Butran A, Velasco P, Ordas A, Malvar RA. Yield evaluation of maize cultivars across environments with different levels pink stem borer infestation. 2004. Crop Sci. 44:741-747.

4. Baafi, E. and O. Safo-Kantanka. Correlation and path coefficient analysis for earliness and yield traits in cotton (G. hirsutum L.). Asian J. 2008.

5. Cotton handbook. Cotton Growers Association. Cotton Training centre, Kadoma, Zimbabwe

6. Mare M, Manjeru P, Ncube B and Sisito G. GGE biplot analysis of genotypes by environment interaction on Sorghum Bicolor L. (Moench) in Zimbabwe. 2017. African Journal of Crop Science. http://www.researchgate.net.

7. Mudada N, Chitamba J, Macheke T. O, Manjeru P. Genotype x Environmental Interaction on seed cotton yield and yield components. Open Access Library Journal 4: e3192. 
http://doi.org/10.4236/oalib.1103192

8. Mukoyi F, Gasura E and Makunde G.S. Implications of correlations and genotype by environment interactions among cotton traits. 2018. African Crop Science Journal, Vol. 26, No. 2, pp. $219-235$

9. Nzuve, F.; Githiri, S.; Mukunya, D.; Gethi, J. Analysis of genotype x environment interaction for grain yield in maize hybrids. Agric. Sci.2013, 5.

10. Simasiku M.L, Lungu D. M and Tembo L. Genotype by Environment Interaction of Cotton Genotypes for Seed Cotton Yield in Zambia

11. Travella SR. Cotton in Africa. 2017. Retrieved from http://www.vib.be/en/aboutvib/Documents/vib_fact_CottonAfrican_EN_2017_0901_LR_FINAL.pdf

12. Williams Lynne J. and Herv`e Abdi. Fisher's Least Significant Difference (LSD) Test. In Neil Salkind (Ed.), Encyclopaedia of Research Design. Thousand Oaks, CA: Sage. 2010.

13. Yan WK, Hunt LA, Sheng Q, Szlavnics Z. Cultivar evaluation and mega-environment investigation based on the GGE biplot.2000. Crop Sci. 40:597-605.

14. Yan WK. GGE biplot-A windows application for graphical analysis of multi-environment trial data and other types of two-way data.2001. Agron. J. 93:1111-1118

15. Yan W, Hunt LA. Biplot Analysis of Multi-Environment Trial Data In Quantitative Genetics, Genomics and Plant Breeding. Kang, M. S., (Ed.), CABI Publishing, New York. 2002. pp. 289-303.

16. Yan W, Kang MS. GGE biplot analysis: A graphical tool for Breeders, Geneticist and Agronomist. 2003. CRC press LLC, Boca Roton, Florida, USA.

17. Zeng, L.; Meredith, J.; Campbell, B.T.; Dever, J.K.; Zhang, J.; Glass, K.M.; Jones, A.S.; Myers, G.O.; Bourland, F.M. Genotype-by-environment interaction effects on lint yield of cotton cultivars across major regions in the US cotton belt. Cotton Sci.2014, 18, 75-84

\section{Figures}

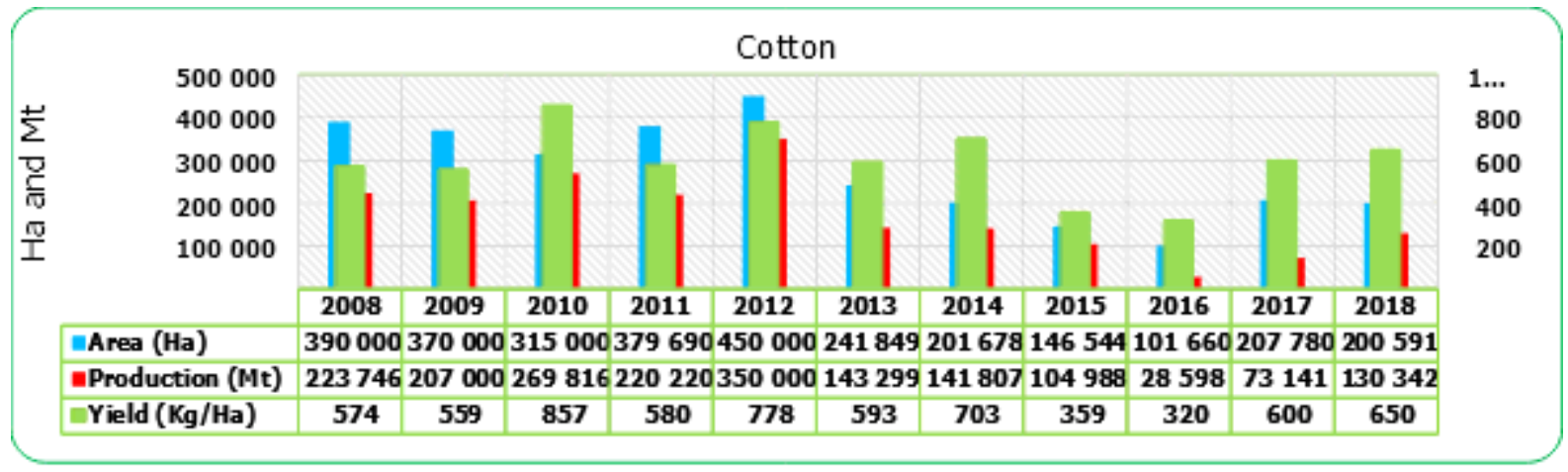

\section{Figure 1}

Cotton production trend (average yield, production and area under production) for the period 2008 -2018 (Source: AMA 2019). 


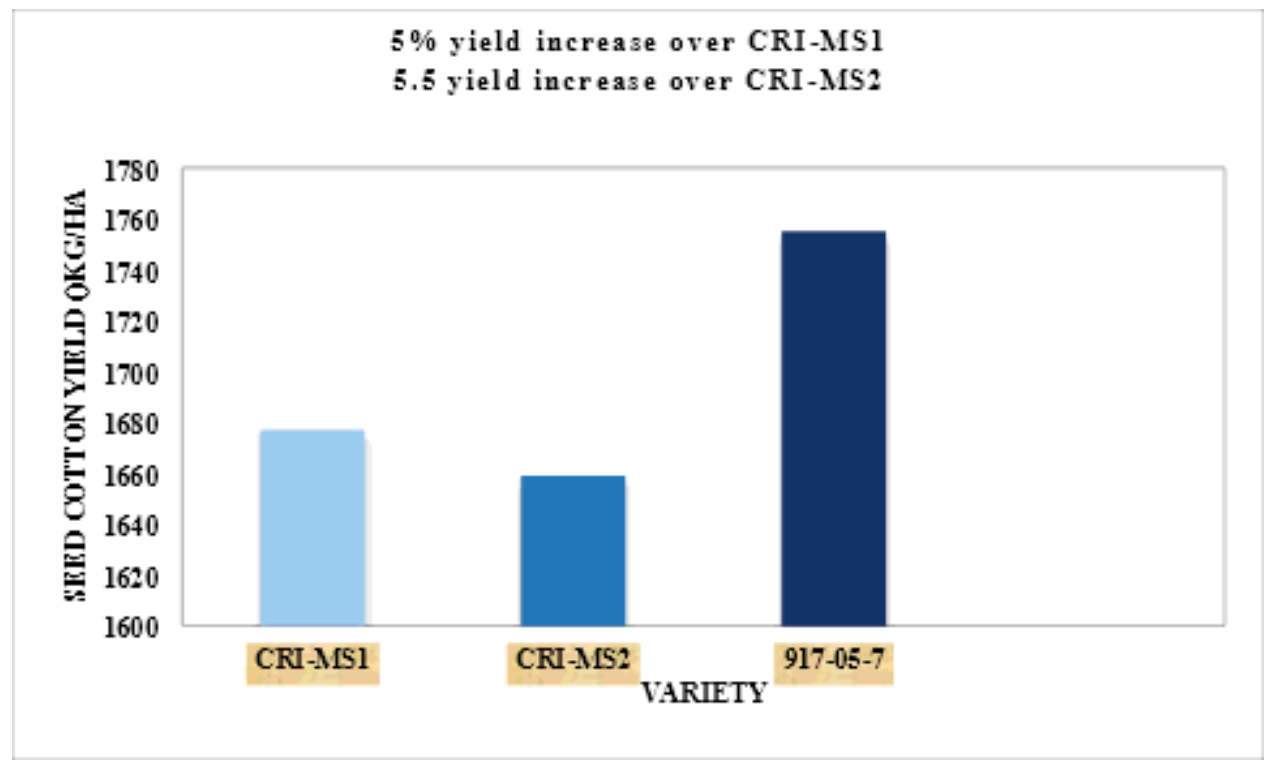

Figure 2

Overall seed cotton yield performance of 917-05-7 and percentage increase over check varieties over five seasons 
Scatter plot (Total - $59.08 \%$ )

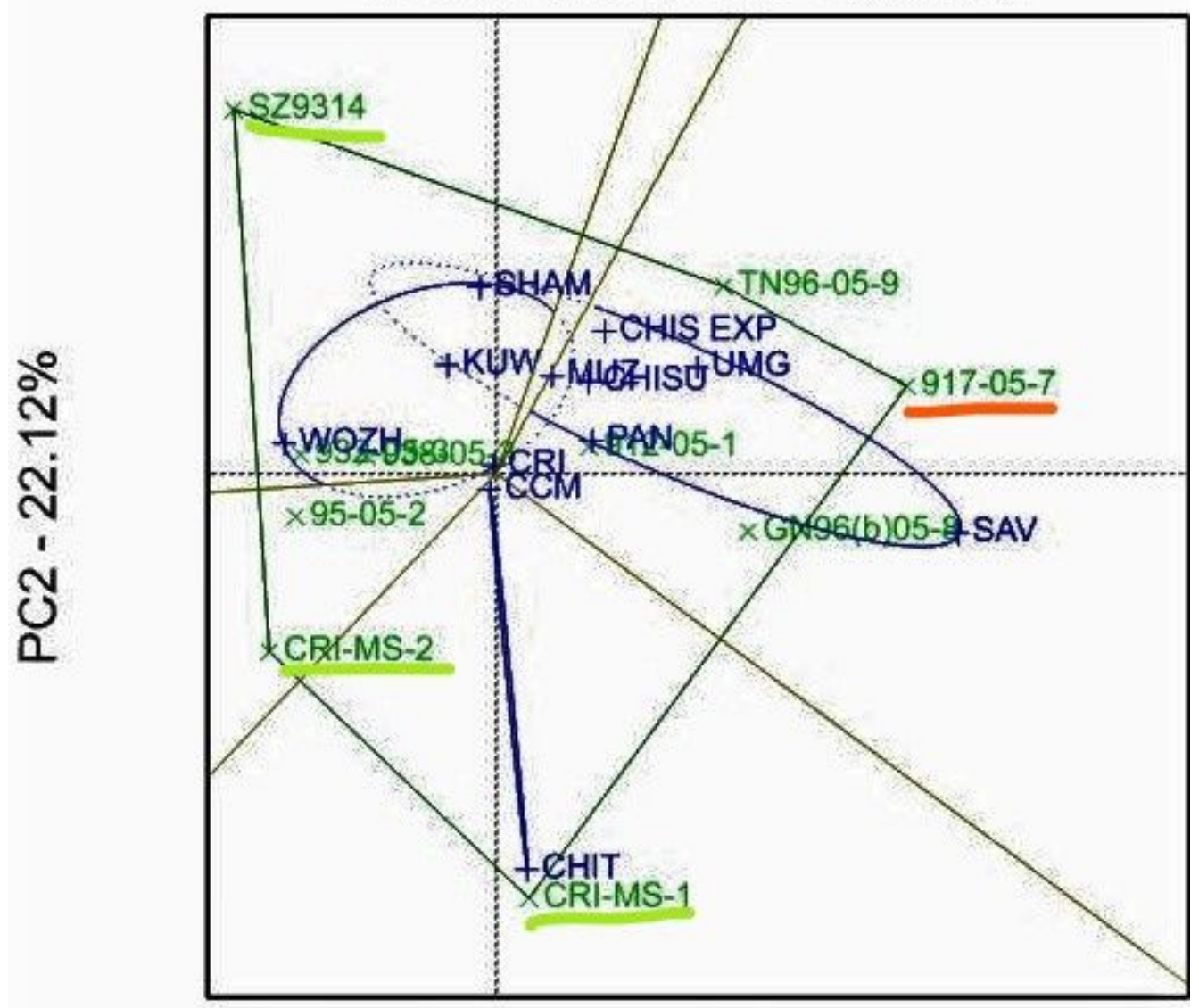

\section{PC1 - $36.96 \%$}

\begin{tabular}{|ll}
$\times$ & Genotype scores \\
$+\quad$ & Environment scores \\
\hline & Convex hull \\
\hline & Sectors of convex hull \\
\hline & Mega-Environments
\end{tabular}

Figure 3

Best performing genotypes (Which-won-where) and mega-environments 


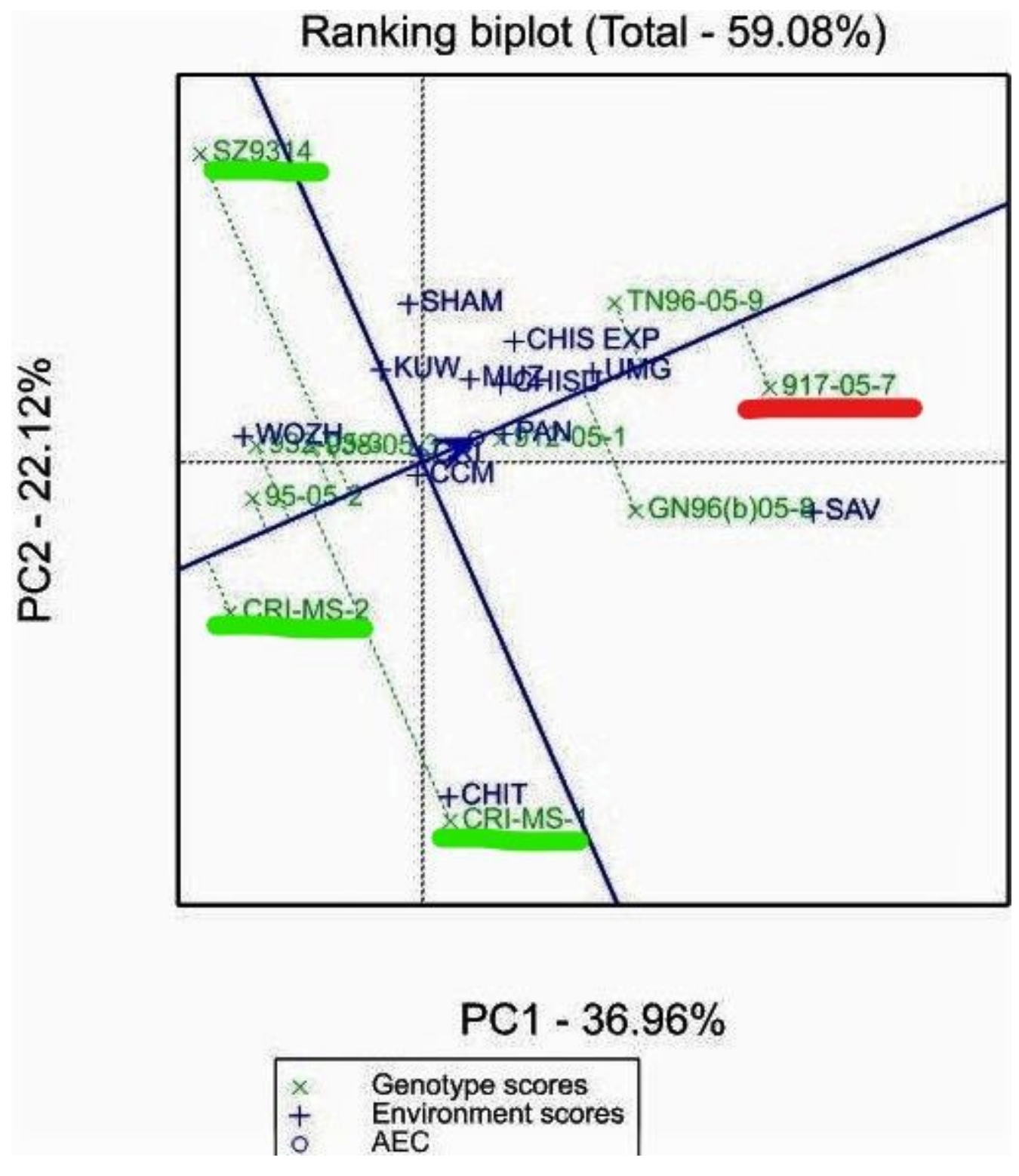

Figure 4

Ranking biplot showing the high yielding and stable test genotypes 

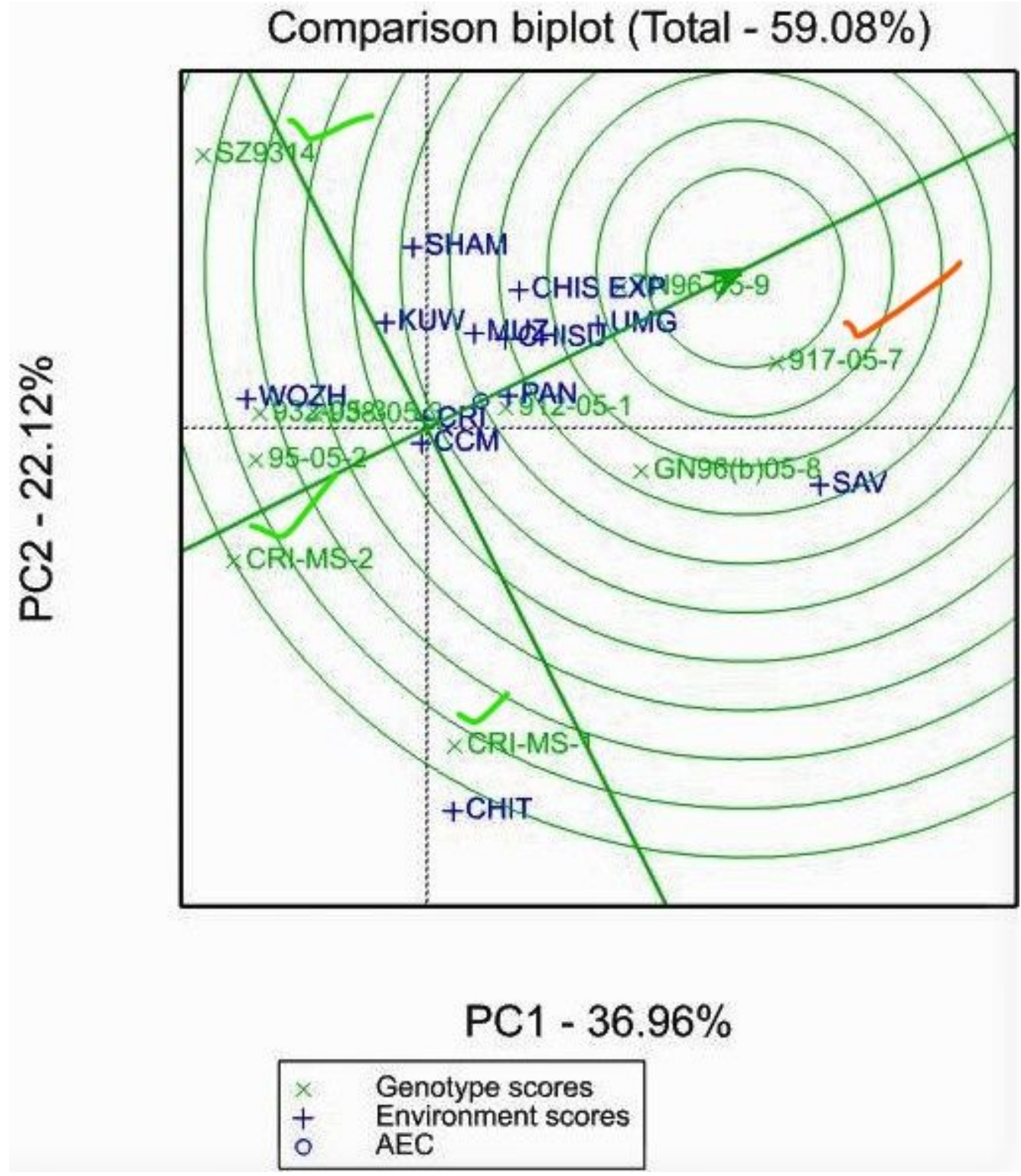

Figure 5

Comparison biplot showing the ideal genotype and ideal environment 